\title{
Academic Application at STIEM Bongaya Makassar Web-Based
}

\author{
Usman $^{* 1}$, Sitti Harlina ${ }^{2}$ \\ ${ }^{1,2}$ STMIK Dipanegara, Makassar, STMIK Dipanegara Makassar \\ e-mail: "11 usman@dipanegara.ac.id, ${ }^{2}$ sittiharlina@ dipanegara.ac.id
}

\begin{abstract}
This study aims to design a web-based academic information system at STIEM Bongaya Makassar. During this academic service to students is still done manually, for example at the end of the semester students usually queue up to see grades and class schedules that use paper media that is posted on the bulletin board, so servants to students become ineffective and inefficient. With the advancement of information technology such as internet media, it can support the academic activities of a college. So with the use of internet media students do not need to come directly to the lecture to get academic information The web-based academic information system at STIEM Bongaya Makassar is expected to provide convenience in managing student data and academic services. This academic information system will later be web-based created using the Php and MySQL programming languages as a database, and white box testing as a testing method to find out whether an application has been made free of logical errors
\end{abstract}

Keywords - STIEM Bongaya Makassar, Information Systems, Academic, Web, Php, MySQL

\section{INTRODUCTION}

In today's technological developments everything is done all modern, easy and practical. Technology for humans is used as a means of communication to exchange or search for information anywhere, because with the rapid advance of technology gives a great influence on communication patterns in society. Internet connection is one of the results of technological advances today, where with the internet connection everyone can find information about things wherever they are, as well as the academic community environment in universities, which can support the academic activities of a college ${ }^{[1]}$. Academic is a change in ability caused by the learning process. The resulting form of the learning process can be written or oral solving, skills and problem solving that can be measured and assessed using standardized tests ${ }^{[2][3]}$. This is supported by a statement stating that academic achievement is the result achieved by students over a certain period of time in certain subjects manifested in numbers and formulated in raport ${ }^{[4]}$. Academic achievement is the level of achievement of success towards a goal, because a learning effort has been carried out optimally ${ }^{[5]}$. While academic achievement according to Opit in ${ }^{[6]}$ is the school output which is a tool to measure students' cognitive abilities.

The use of internet media is very necessary for students in obtaining information about academics, because with the use of internet media students do not need to come directly to the lecture place to get academic information.

College of Economics and Management (STIEM) Bongaya Makassar is one of the universities that do not have an academic information system, so far academic services to students are still carried out in a manual way, by way at the end of the semester students queue to see the grades and schedule of lectures affixed to the bulletin board, so that information servants are often late, academic Information System a system built to manage academic data so as to provide convenience for users in campus academic administration activities online ${ }^{[7]}$. STIEM Bongaya requires a web-based academic information system, which helps in terms of 
academic activities be it leaders, departments, BAAK, lecturers and students so that the interaction process is not hindered location and distance because it can be accessed anywhere and anytime by using internet media.

\subsection{System Characteristics}

The system has certain characteristics or properties consisting of ${ }^{[8]}$ :

1. System Components

A system consists of a number of components that interact with each other or work together to form a unity.

2. System Boundary

A system boundary is an area that restricts between a system and another system or an area that borders between a subsystem and another subsystem, or its outer environment.

3. Environment

The outside environment is something that is outside the system that affects the operation of the system.

4. Interface

System linking is a medium that connects one system to another.

5. System Input

System input is energy that is put into the system in the form of data, maintenance input and signal input.

6. System Output

System output is the result of energy processed in the form of information and classified into useful outputs from residual disposal. System Processing

7. System processing is a part of the system that processes input into output.

8. Goal System (Goal)

\subsection{Information Systems}

An information system is a system within an organization that brings together the needs of daily transaction processing, supports operations, is managerial and in the form of strategic activities of the organization and provides the needs of certain outside parties with the necessary reports ${ }^{[9]}$.

\subsection{System Design}

Determination of specifications that meet the needs and requirements specified during the system analysis stage. The purpose of system design is to meet the needs of the system user and to give a clear picture to computer programmers ${ }^{[10]}$.

\subsection{System Design Steps}

The system design steps are as follows:

a) Identify the problem

A problem needs to be identified first to find out what problems are found and how to find a solution.

b) Understand the workings of the existing system

By conducting research on objects to be researched about the operating system.

c) Analyzing the system

By trying and concluding the working process of the system.

d) Implementation and testing

Application and testing of the system into actual conditions in order to be known its shortcomings and advantages. 
e) Analysis report

By making an analysis report as the next draft.

\section{RESEARCH METHOD}

In this research, the types of research conducted are as follows: Research library, and field research. In this research activity, using several methods that are used as a way of collecting data needed, namely: Interview Method (Interview), Observation Method (Observation) and Questionnaire Method.

\section{RESULTS AND DISCUSSION}

\subsection{Running Systems}

Data processing in STIEM Bongaya Makassar is still done computerized without a database using MS. Excel where the information received and services to students are still going through an inefficient data process so that the information needed is often too late. The current system is described with the Document Flowchart as follows:

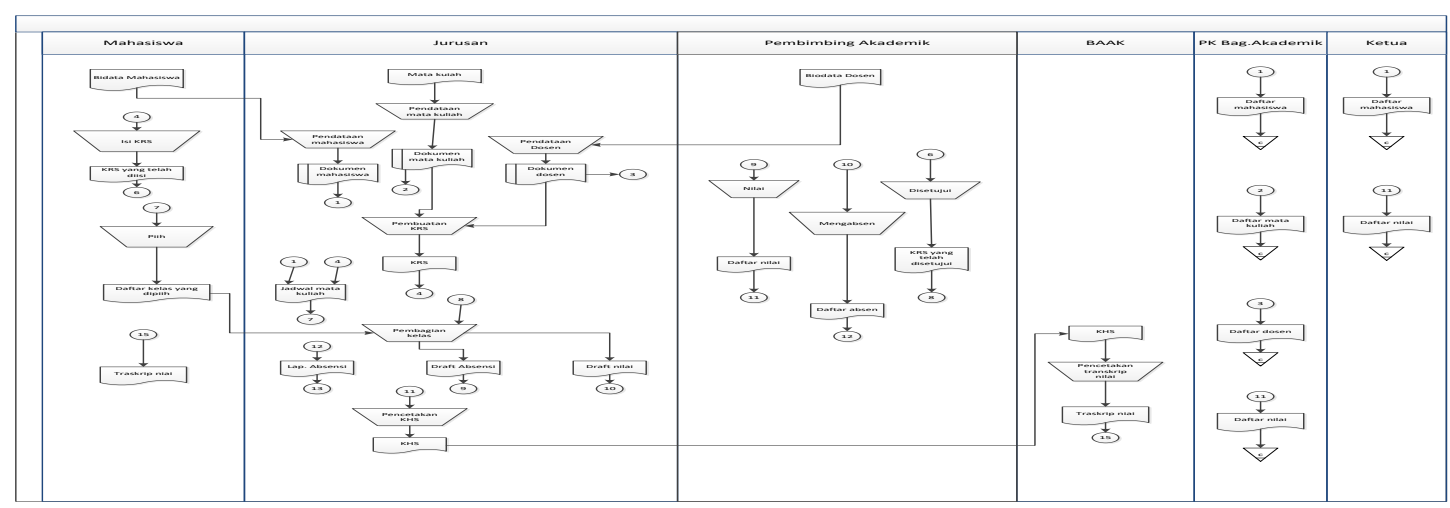

Figure 1. Running System Document Flow Chart

\subsection{Proposed Systems}

From the analysis of the system running on STIEM Bongaya Makassar and the constraints it causes, the author proposes to build a web-based application by utilizing the internet network.

The proposed system design is as follows: 


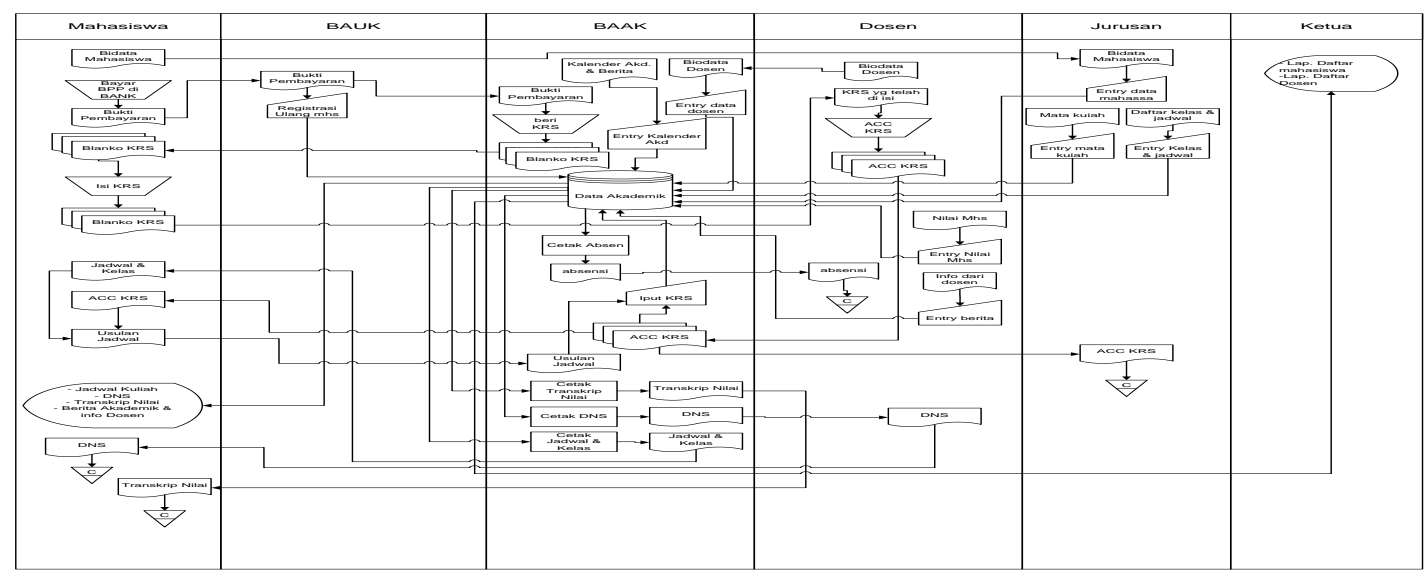

Figure 2. Proposed System Document Flow Chart

\subsection{Context Diagrams}

A context diagram is a chart that displays. A. A process intended to describe the system/software in general. The diagram describes processes related to the environment, there are outside parties or environments that provide input and there are parties that receive system input.

The context diagram of the proposed Software is as follows:

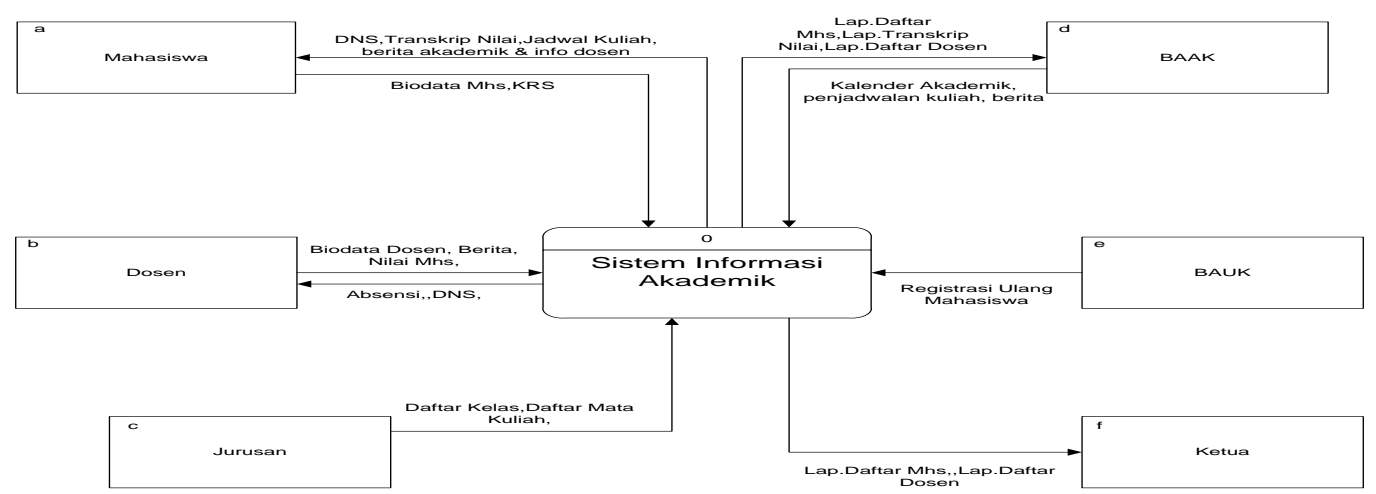

Figure 3. Context Diagram

\subsection{Tiered Diagrams}

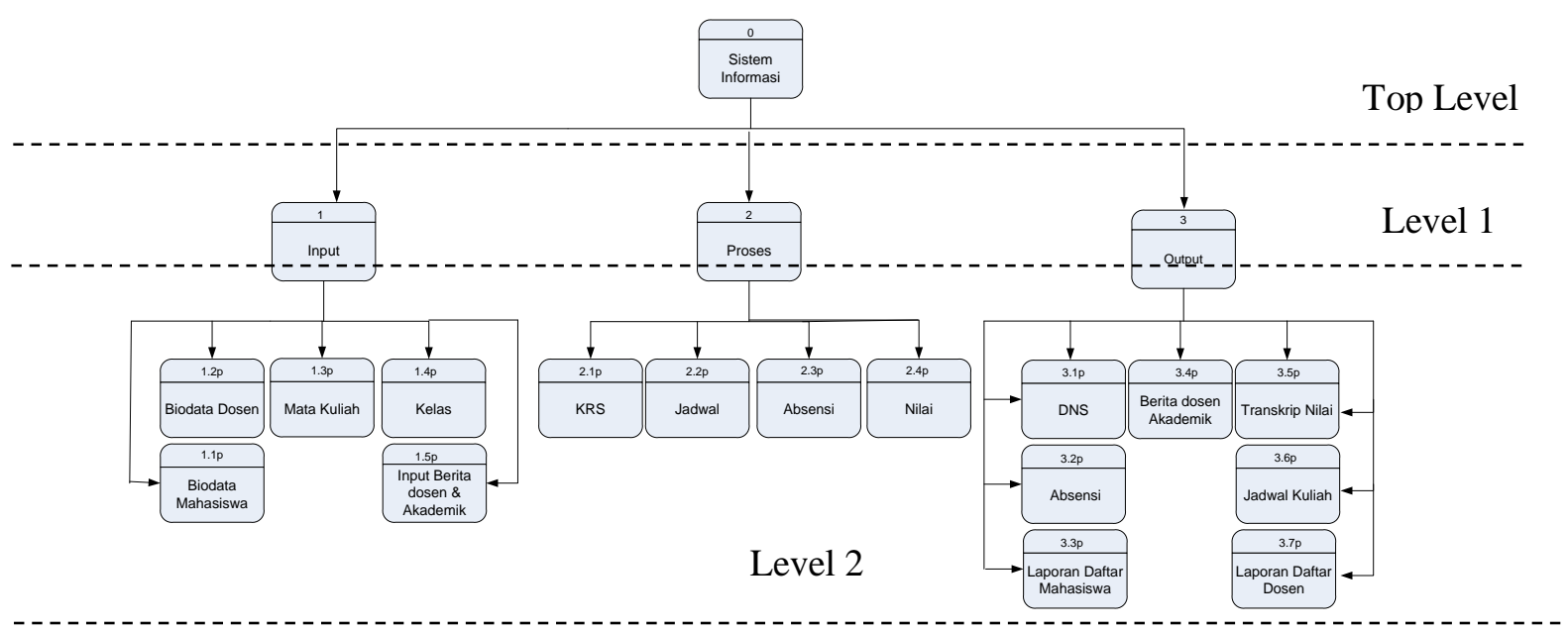

Figure 4. Tiered Diagrams 


\subsection{Output Design}

The following is the output design interface of the web-based Academic Information System at STIEM Bongaya Makassar:

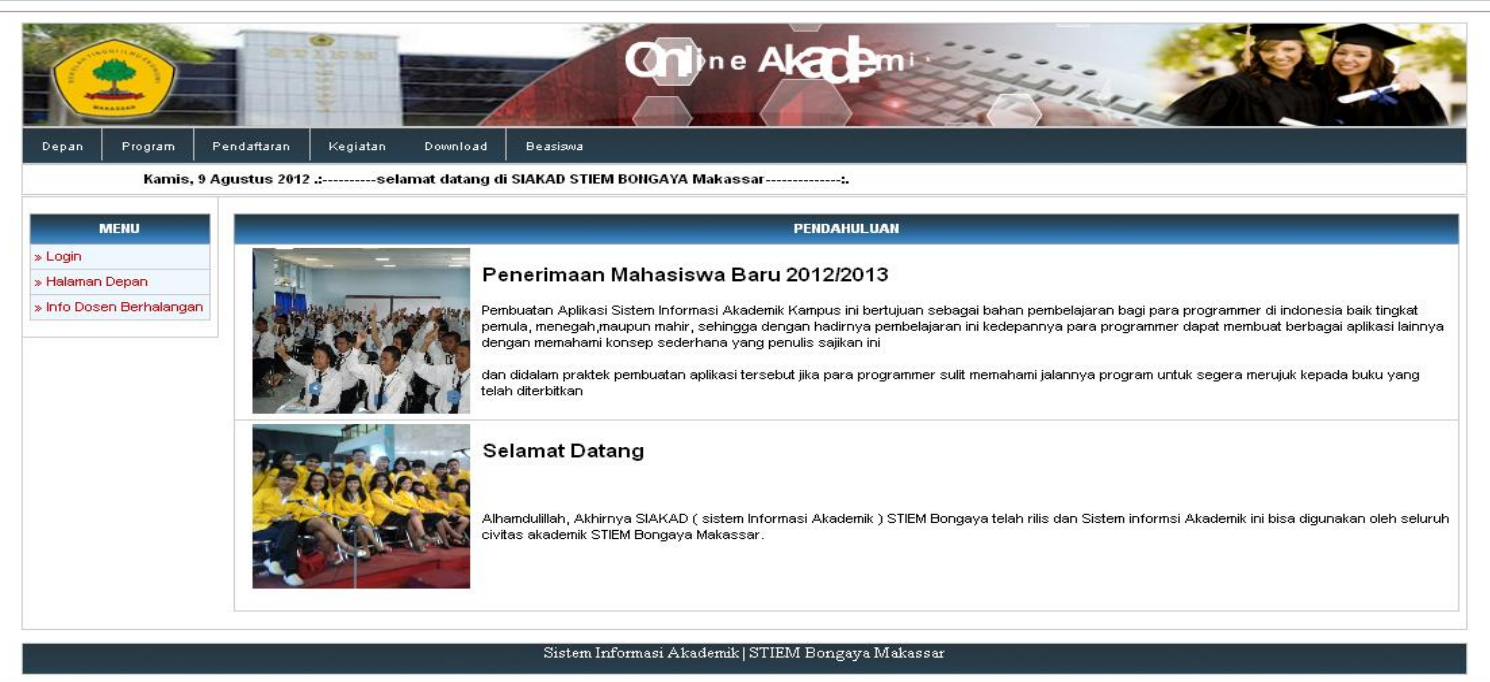

Figure 5. Home Design

In figure 5, the design of the Home form consists of pictures of activities at STIEM Bongaya Makassar such as New Student Admissions and welcome.

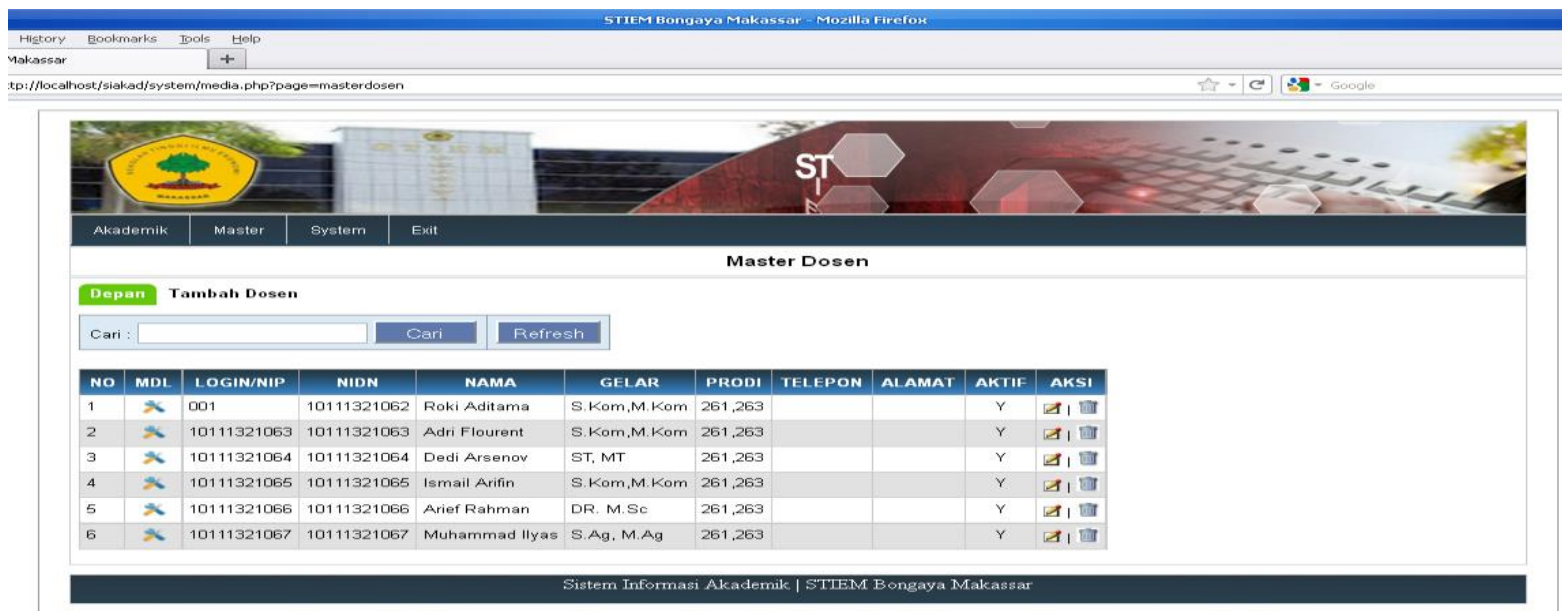

Figure 6. Draft Form View Lecturer Data

In figure 6, the draft form of Lecturer Data View consists of fields (No, MDL, Login/NIP, NIDN, Name, Degree, Study Program, Telephon, Address, Active and Action. 


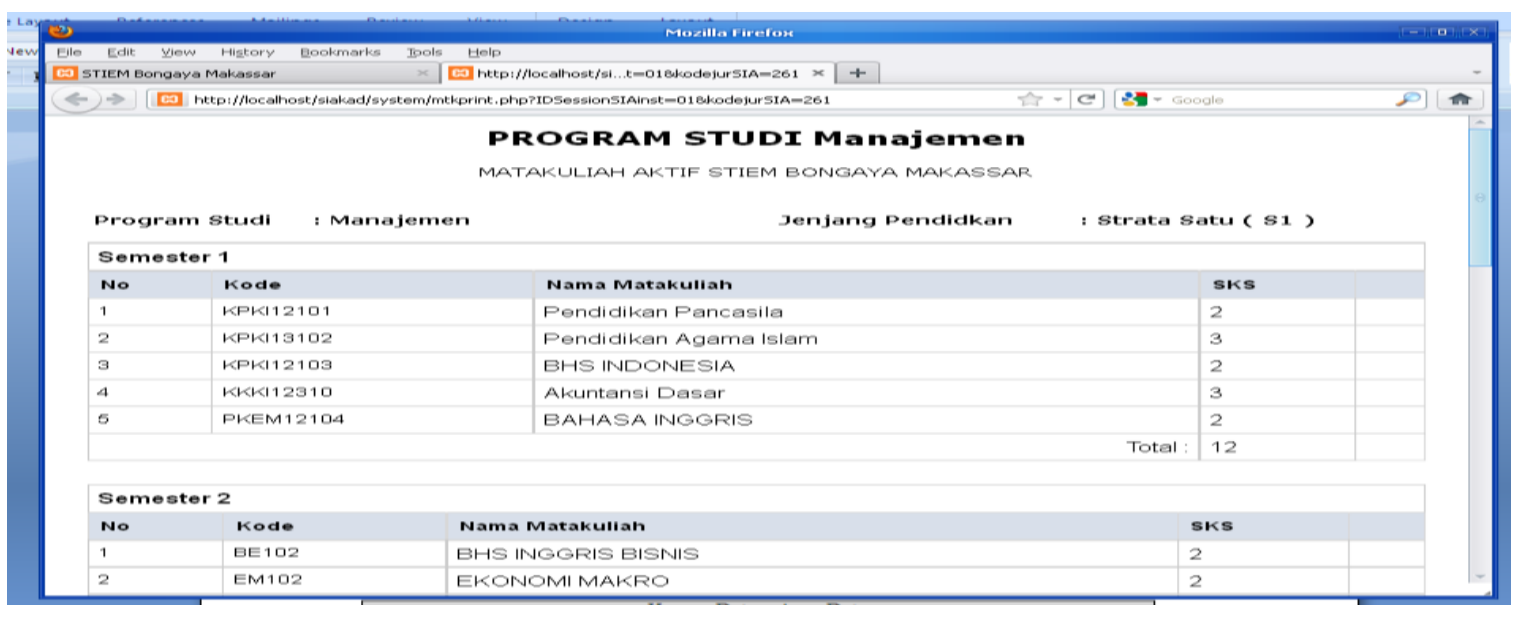

Figure 7. Course Data Form Design

In figure 7 is the Draft Form View Data Courses consisting of fields (No, Code, Mama Courses and SKS.

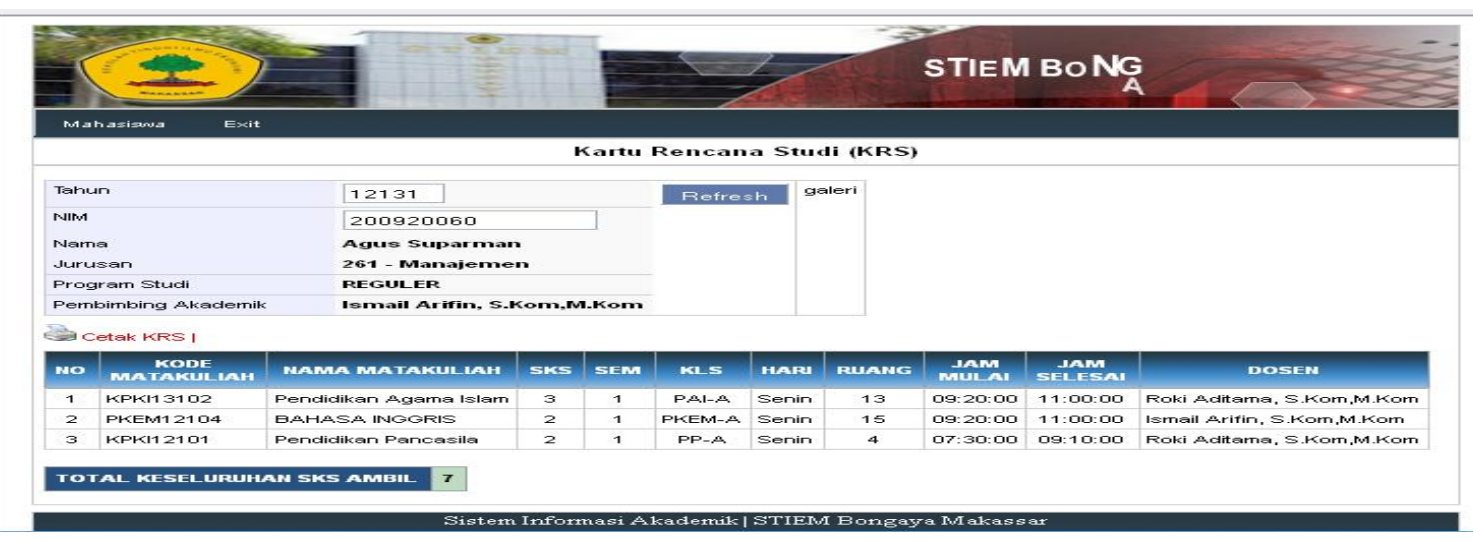

Figure 8. Krs Form View Design \& Student Schedule

In Figure 8 of the krs form view design and student schedule consists of fields (Year, NIM, Name, Department, Study Program and Supervisor. To print KRS, field will appear (No. Course Code, Course Name, SKS, SEM, Kls, day, Room, Start Time and Finish Time, Lecturer.

\subsection{Input Design}

Berikut ini adalah interface rancangan input dari Sistem informasi akademik pada STIEM Bongaya Makassar : 


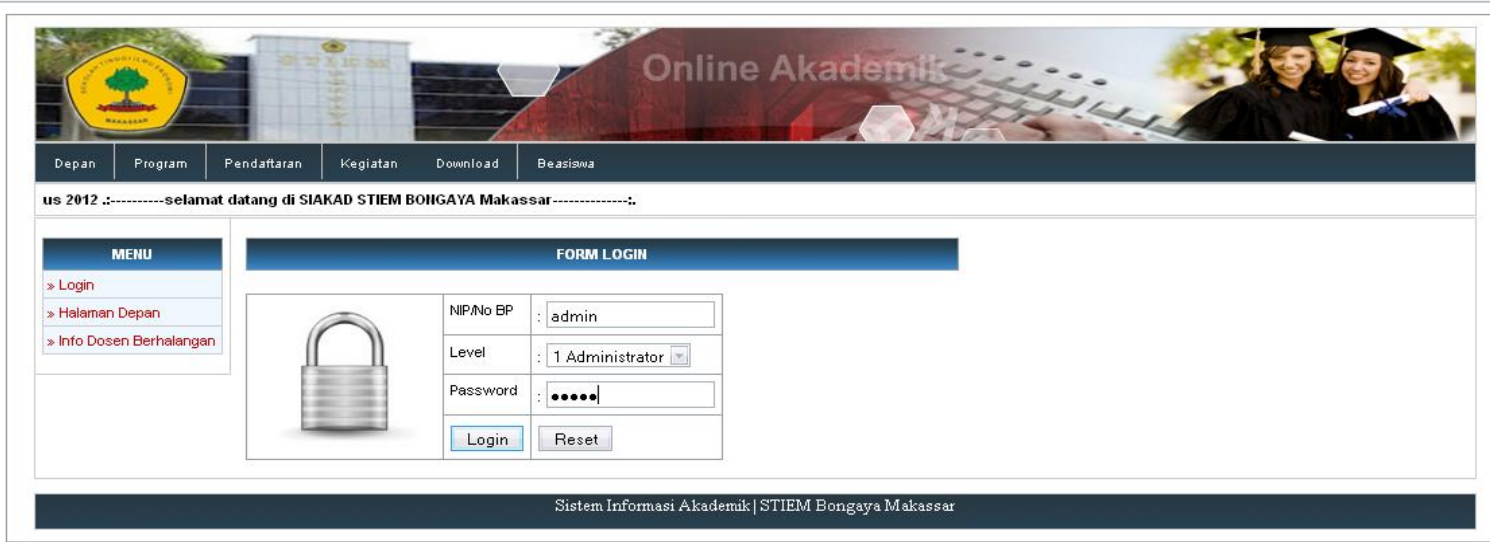

Figure 9. Input login user \& Administrator

In figure 9 the Draft User And Administration Login Input form consists of NIP, Password Level and Login. If you want to delete, press Reset.

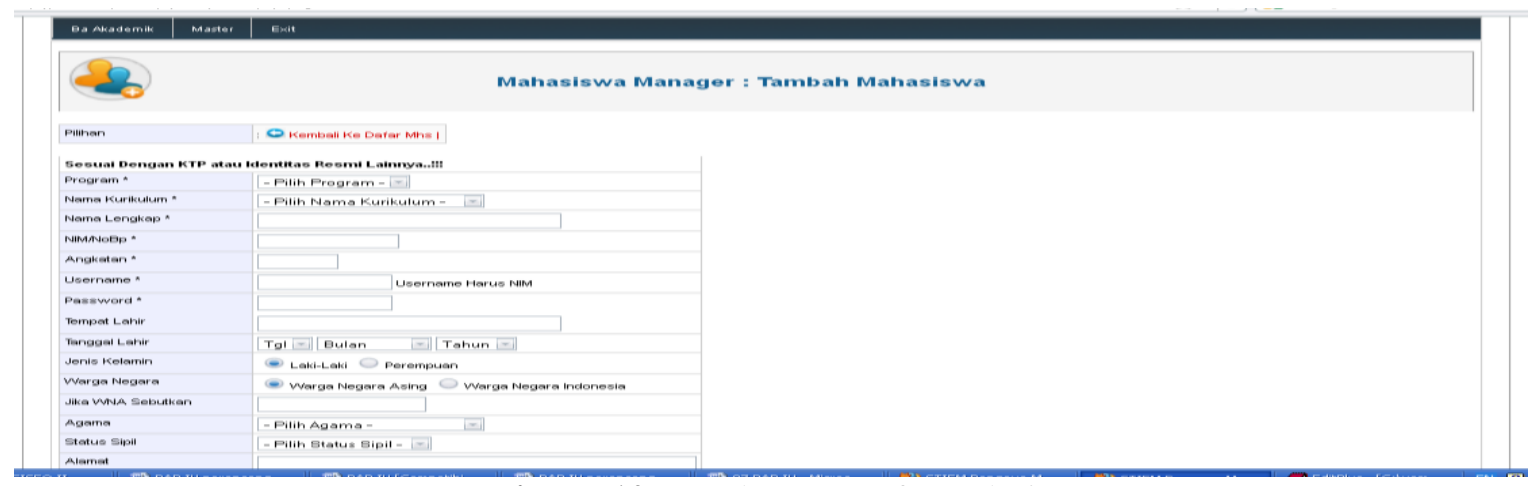

Figure 10. Student Input form design

In Figure 10 the Student Input Form Design consists of a field (Program. Curriculum Name, Full Name, NIP, Force, Username, Password, place of Birth, Gender, Citizen, Religion, Civil Status and Address).

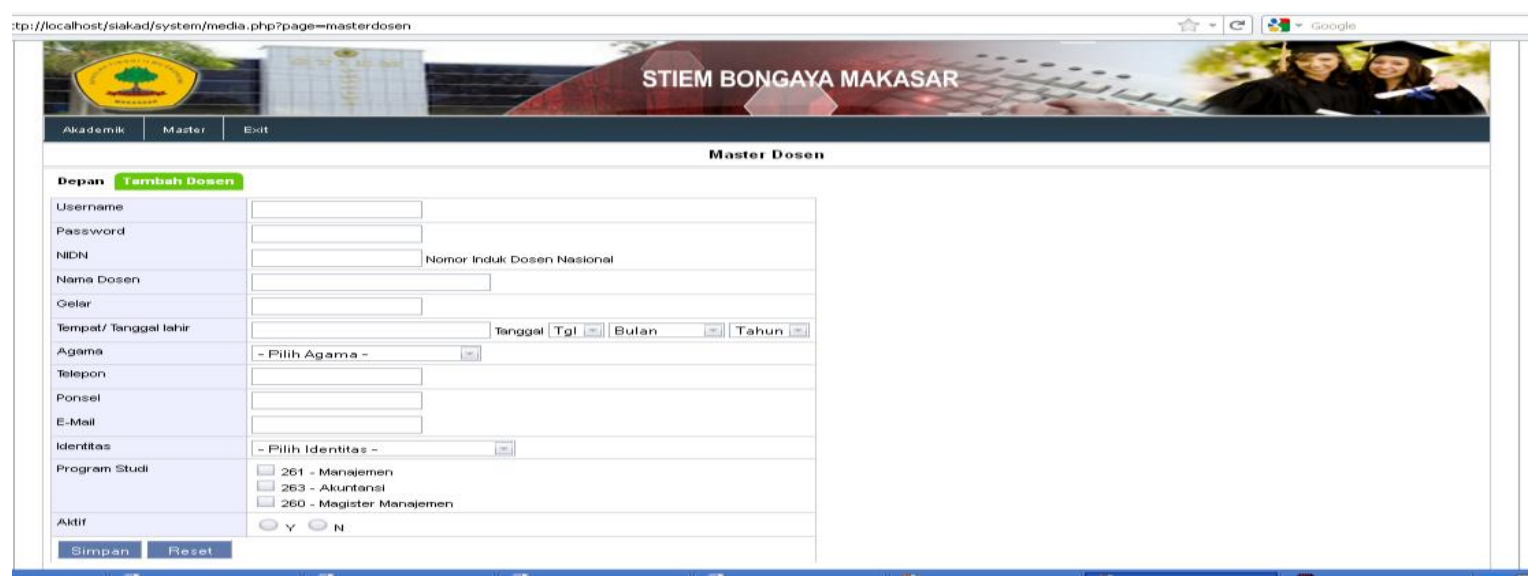

Figure 11. Draft Of Lecturer Data Input Form

In figure 11 of the Draft Data Input Form lecturers consist of several fields (Username, Password, NIDN, Lecturer Name, Degree, Place / Date of Birth, Religion, Telephon, Mobile Phone, Email, Identity and Study Program and student's authoriative). When it is all input, it is saved or reset. 


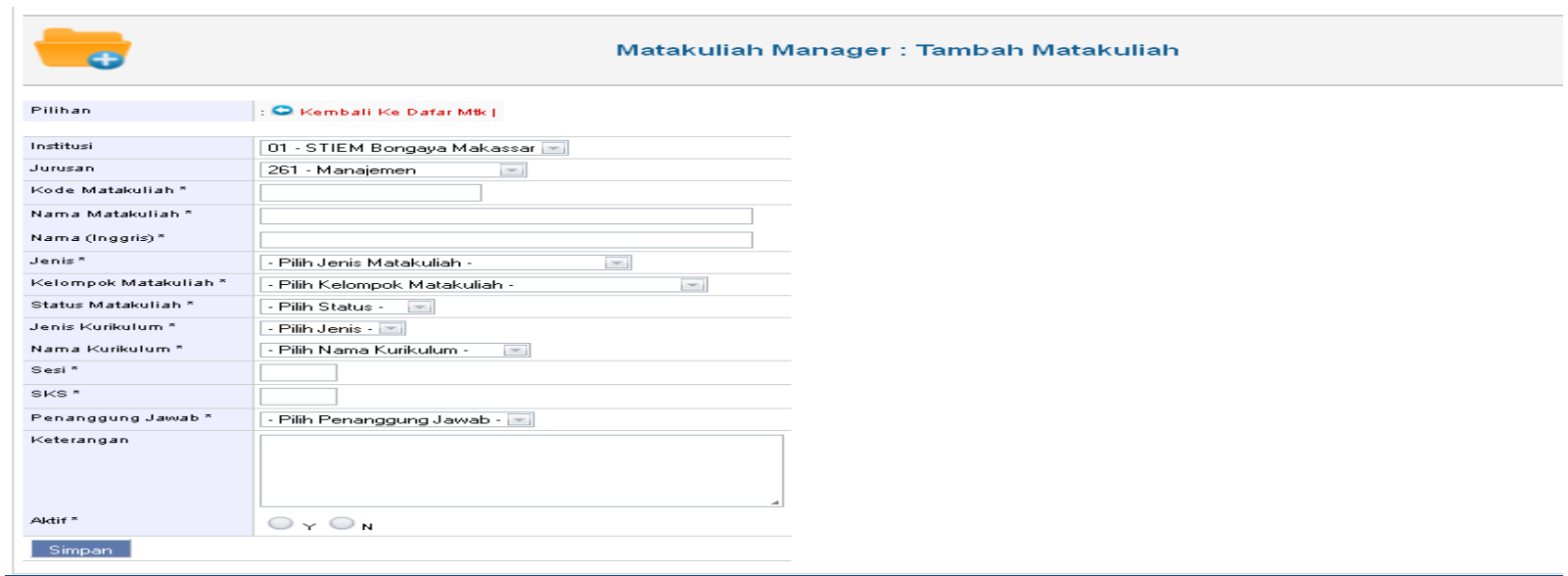

Figure 12. Course Input Form Design

In Figure 12. Draft Course Input Form consists of field (Options, Major Institution, Course Code, Course Name, Name (English) Type, Course Group, Course Status, Curriculum Type, Curriculum Name, Session, SKS, Person in Charge and description, Active). If it has been inputted all then click Save then the course data will be saved.

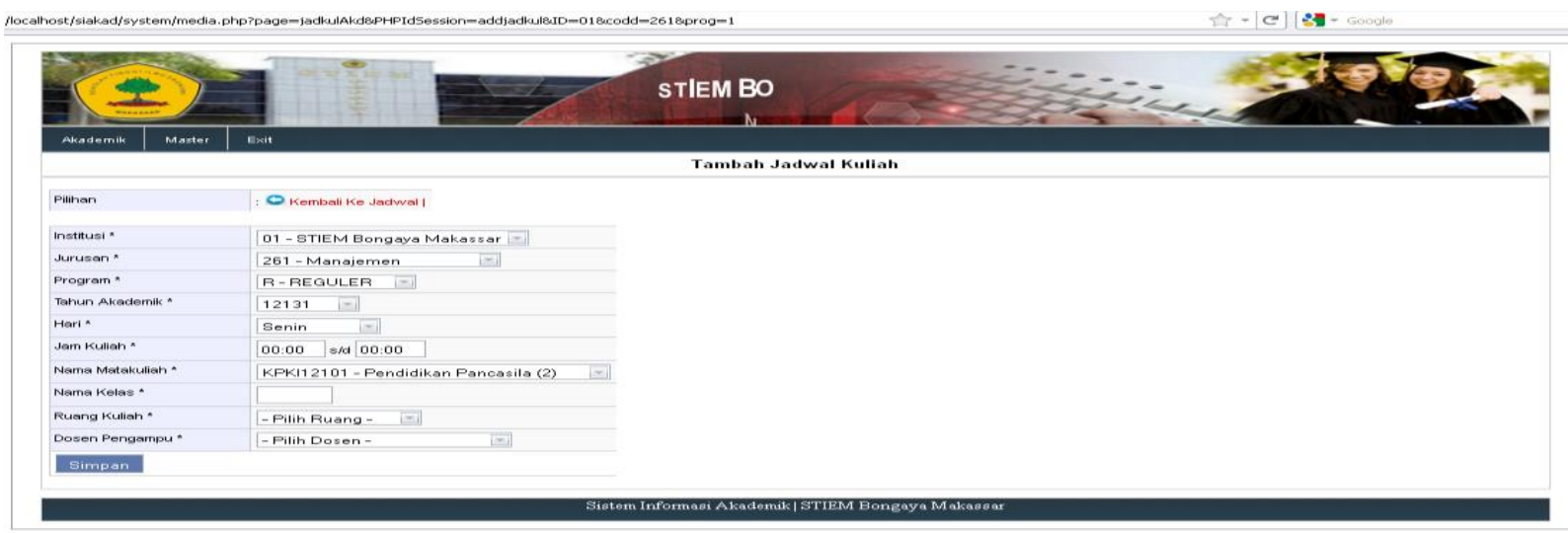

Figure 13. Schedule Input Form Design, Class \& Room

In Figure 13. Draft Input Form Schedule, class \& Room consists of Field (Institution, Department, program, Academic Year, day, lecture hours, Course Name, Class Name, Lecture Room and Lecturer Forgiving). If it has been inputted all then we click save then all data will be saved.

\section{CONCLUSION}

Based on the results of the research, it can be drawn some conclusions and suggestions as follows:

1. Data processing system used so far in STIEM Bongaya Makassar still use manual system that causes delays in information and services to students.

2. It is expected that the existence of this web-based academic information system, can overcome the problems that occur in terms of data processing and services to students. 


\section{REFERENCES}

[1] Recky T.Djaelangkara, Rizal Sengkey \& Oktavianus A.Lantang, 2015, Perancangan Sistem Informasi Akademik Sekolah berbasis Web (Studi Kasus Sekolah Menengah Atas Kristen 1-Tomohon), E-Jurnal Teknik Elektro dan Komputer ISSN:23018402.UNSRAT.

[2] Green Ferry Mandia, 2017. Analisis Pengaruh Pemanfaatan Smartphone Terhadap Prestasi Akademik Mahasiswa Fakultas Ilmu Komputer Universitas Klabat. Cogito Smart

[3] Davis, F.D., Bagozzi, R.P. and Warshaw, P.R. 2014. "User Acceptance of Computer Technology: A Comparison of Two Theoretical Models," Management Science (35:8), pp. 982

[4] Alex Sobur. (2015). Psikologi Umum. Bandung: Pustaka Setia.

[5] Dewi, D.P. (2017). Hubungan Karakteristik Smartphone Pada Perubahan Budayan Komunikasi Remaja Di RT 12 Kelurahan Sempaja Selatan Samarinda. Available : http://ejournal.ilkom.fisip-unmul.ac.id/site/wp-

[6] Nuraeni, A. (2014). Pengaruh Kualitas Perkawinan, Pengasuhan Anak dan Kecerdasan Emosional Terhadap Prestasi Belajar Anak. Bogor : Institut Pertanian Bogor.

[7] Titasari Rahmawati, Restu Hendriyani, 2019, Perancangan dan Pengembangan Website SMK PGRI2 Jombang sebagai Media Informasi Program Sekolah, jurnal pengembangan dan Penerapan IPTEKS. Jombang Jawa Timur.

[8] Jogiyanto H.M. 2013. Analisis dan Desain Sistem Informasi, Pendekatan Terstruktur Teori dan Praktek Aplikasi Bisnis, : cetakan ke IV, Andi Offset. Yogyakarta

[9] Robert A. Leitch dan K. Roscoe Davis, 2014, Sistem Informasi, PT. Prenhallindo, Jakarta.

[10] Robert J., Verzello, John Reuter III, 2015, International Student Edition, McGraw-Hill Kogakusha, Tokyo. 